\title{
Genetic characterization of porcine circovirus type 2 (PCV2) from wild boars detected in different regions of Ukraine
}

\author{
L. V. Dudar, I. G. Budzanivska, V. P. Polishchuk \\ ESC "Institute of Biology and Medicine", Taras Shevchenko National University of Kyiv \\ 64/13, Volodymyrska Str., Kyiv, Ukraine, 01601 \\ liudmyla.dudar@hipra.com
}

\begin{abstract}
Aim. Circovirus type 2 is a common swine virus in industrial farms worldwide, including Ukraine. PCV2 infection leads to an immunosuppressive condition and high mortality of animals. Methods. Due to the variety of PCV-2 strains in the world, and the difference between wildlife and farm strains, we undertook the characterization of field isolates found among wild boars in Ukraine using phylogenetic analysis. Results. We have shown that isolates from the Chernihiv, Zaporizhzhya, Cherkasy and Kharkiv regions belong to different subgroups of the PCV-2 and have different origins. In addition, a relatively high level of similarity with the isolates from Croatia and Brazil was found. At the same time, the isolates from wild boars from the Zaporizhzhya and Chernihiv regions, were found to be similar to that from pigs from industrial farms. Conclusions. A high level of genetic diversity was found among the investigated isolates of PCV-2 isolated from wild boars in Ukraine. The fact that some of the isolates of PCV-2 from wild boars characterized by high level of simillarity with isolates, from pigs of industrial farms, indicates an existing pathway for the transmission of the virus between demarcated animal populations and requires further research.
\end{abstract}

Ke y w or d s: porcine circovirus type 2, wild boar, phylogenetic analysis, genetic diversity.

\section{Introduction}

Porcine circovirus type 2 (PCV2) impacts global swine production, is economically important, and is associated with multiple disease entities including multisystemic disease, wasting, pneumonia, diarrhea and reproductive failure. Porcine circovirus (PCV), which belongs to the family Circoviridae, genus Circovirus [1], is one of the smallest animal viruses with unenveloped, singlestranded circular genome and a size of $17 \mathrm{~nm}$ in diameter $[2,3]$. Two species of PCV, PCV1 and PCV2, have been characterized [4]. PCV1 is considered to be nonpathogenic to pigs by experimental inoculation [1], and has originally been identified as a persistent tissue culture contaminant in pig kidney cell lines [5]. PCV2 has been shown to be the causative agent of the post-weaning multi-

(C) 2018 L. V. Dudar et al.; Published by the Institute of Molecular Biology and Genetics, NAS of Ukraine on behalf of Biopolymers and Cell. This is an Open Access article distributed under the terms of the Creative Commons Attribution License (http://creativecommons.org/licenses/by/4.0/), which permits unrestricted reuse, distribution, and reproduction in any medium, provided the original work is properly cited 
systemic wasting syndrome (PMWS) of pigs $[6,7]$.

At least, five Open Reading Frames (ORF) have been reported to be effectively transcribed, but the most studied and widely sequenced region is the ORF2, which encodes for the Cap protein. This protein represents the only component of the viral capsid and has been proven to be the major target of the host immune response. The ORF2-based classification criteria have been collectively adopted to define the PCV2 genotypes because of its higher phylogenetic signal and lower tendency to recombine. The PCV2 geographical distribution and its wide presence have been undoubtedly linked to livestock movements and trade routes leading to the rapid spread of new strains in various countries. The PCV2 genotype $2 \mathrm{a}$ is considered to be prevalent until 2003, when a change in genotype prevalence (commonly known as a genotype shift) occurred in favour of the genotype $2 b$, with a parallel enhancement of the outbreak severity. A similar situation happened again in 2010 when the genotype $2 \mathrm{~d}$ appeared and rapidly spreaded to the detriment of PCV2b prevalence. The aforementioned high evolutionary rate (about $10^{-3}-10^{-4}$ substitutions/site/year) and the huge viral population size provide optimal conditions for natural selection to act. One of the suggested reasons for its wide acquired genetic variability could reside in a selective pressure promoted also by the vaccination-induced immunity escape [8].

Consequently, the wild swine population represents a major source of genetic variability and/or simply of viral exchange, but it is not concerned by the vaccination burden (Porcine circovirus type 2, PCV2) evolution before and after the vaccination introduction.
The aim of this study was to bring together the available genomic information on the wild and domestic pig PCV2 strains from different regions of Ukraine to explore their evolutionary pathways.

\section{Materials and Methods}

Field samples: clinical samples (serum samples and lymph nodes) from the different farms in high pig density provinces of Ukraine submitted to Molecular Diagnostic Laboratory at CVD (Center of Veterinary Diagnostics) during 2014 2015 were included in this study. These samples were kept at $-80^{\circ} \mathrm{C}$ until performing DNA extraction and PCR. Viral DNA was extracted from lymphoid tissue homogenates and serum samples using NucleoSpin Extract Viral DNA Kit (Macherey-Nagel, Düren, Germany) according to the manufacturer's instructions.

PCR amplification: A full-length ORF2 gene of PCV2 was amplified in $50 \mu 1$ of reaction mixture by PCR with forward primer, PCV2-f1 (5'-CCA TGC CCT GAA TTT CCA TA-3') and reverse primer PCV2-r1 (5'-ACA GCG CAC TTC TTT CGT TT-3') according to Takahagi et al. (2008). The amplification reaction was performed with an initial step at $94^{\circ} \mathrm{C}$ for $2 \mathrm{~min}$, followed by 35 cycles of denaturation at $94^{\circ} \mathrm{C}$ for $30 \mathrm{~s}$, annealing at $60^{\circ} \mathrm{C}$ for $30 \mathrm{~s}$, extension at $72^{\circ} \mathrm{C}$ for $1 \mathrm{~min}$ and a final extension step at $72^{\circ} \mathrm{C}$ for $7 \mathrm{~min}$. The PCV2 positive samples of $702 \mathrm{nt}$ were used for DNA sequencing.

Sequencing and phylogenetic analysis: the PCR products were separated by $1.5 \%$ agarose gel electrophoresis and purified with NucleoSpin Extract II (Macherey-Nagel, Düren, Germany) for the sequences. DNA sequencing was carried out with primers used in the previ- 
ous PCR reaction. A total of 4 sequences from Ukrainian pigs were obtained and translated into amino acid sequences andanalyzed together with the representative complete genome sequences reported in GenBank. A phylogenetic tree was constructed by MEGA 6 software (Tamura et al., 2007) using the neighbor-joining (NJ) method with 1000 bootstrapping replicates (Saitou and Nei, 1987).

\section{Results and Discussion}

All four PCV2 sequences from wild boars detected in Ukraine in this study had a genome length of $1768 \mathrm{nt}$ and revealed nucleotide identities ranged between 99-91.5\% (Tab. 1), indicating no significant difference between PCV2 genotype of wild boars (complete sequences) from different countries.

Ukrainian strains from the Chernigiv, Cherkassy and Zaporigga regions have a common origin with the strains from Brazil and Germany. The strain from Kharkiv has a common origin with the strain from Croatia that was allocated in 2009 .
The evolutionary history was inferred by using the Maximum Likelihood method based on the JTT matrix-based model [9]. The tree with the highest log likelihood (-3225.2487) is shown. The percentage of trees in which the associated taxa clustered together is shown next to the branches. Initial tree(s) for the heuristic search were obtained by applying the BioNJ method to a matrix of pairwise distances estimated using a JTT model. A discrete Gamma distribution was used to model evolutionary rate differences among sites (2 categories $(+G$, parameter $=1.7649))$. The tree is drawn to scale, with branch lengths measured in the number of substitutions per site. The analysis involved 17 amino acid sequences. The coding data were translated assuming a Standard genetic code table. All positions containing gaps and missing data were eliminated. There were a total of 539 positions in the final dataset. Evolutionary analyses were conducted in MEGA6 [10].

The evolutionary history was inferred by using the Maximum Likelihood method based

Table 1. Comparison of Ukrainian isolates of PCV2 from wild boar[s] (AK and NT sequences of complete genome) with PCV2 strains

\begin{tabular}{|l|c|c|c|c|c|c|c|c|}
\hline \multirow{2}{*}{} & \multicolumn{2}{|c|}{ wb_Chernigiv_UA_16 } & \multicolumn{2}{l|}{ wb_Cherkasy_UA_16 } & \multicolumn{2}{c|}{ wb_Charkiv_UA_16 } & \multicolumn{2}{c|}{ wb_Zaporigga_UA_16 } \\
\cline { 2 - 9 } & NK & AK & NK & AK & NK & AK & NK & AK \\
\hline P._circovirus_2_BJ0402 & 98.7 & 97.2 & 99 & 97 & 96 & 91.5 & 99.7 & 99.4 \\
wild_boar_Germ & 95.7 & 91.1 & 96 & 91.3 & 95.7 & 90.4 & 95.9 & 90.9 \\
wild_boar_Croatia_09 & 96.2 & 91.8 & 96.4 & 92 & 99.7 & 99.1 & 96.2 & 91.5 \\
wild_boar_Brazil_12 & 98.8 & 97.8 & 99 & 98 & 96.5 & 92.9 & 98.6 & 96.7 \\
wild_boar_72/12_52_Brazil_12 & 98.5 & 96.5 & 98.6 & 96.3 & 95.9 & 90.9 & 99.4 & 98.7 \\
wild_boar_72/12_49_Br & 98.5 & 96.5 & 98.6 & 96.3 & 95.9 & 90.9 & 99.4 & 98.7 \\
wild_boar_72/12_36_Br & 98.4 & 96.5 & 98.5 & 96.3 & 95.8 & 90.9 & 99.4 & 98.7 \\
wild_boar_72/12_35_Br & 98.5 & 96.5 & 98.6 & 96.3 & 95.9 & 90.9 & 99.4 & 98.7 \\
wild_boar_72/12_34_Br & 98.4 & 96.3 & 98.6 & 96.1 & 95.8 & 90.7 & 99.4 & 98.5 \\
wild_boar_BRA_JAV2_2008 & 98.7 & 97.2 & 98.8 & 97 & 96.1 & 91.5 & 99.7 & 99.4 \\
\hline
\end{tabular}




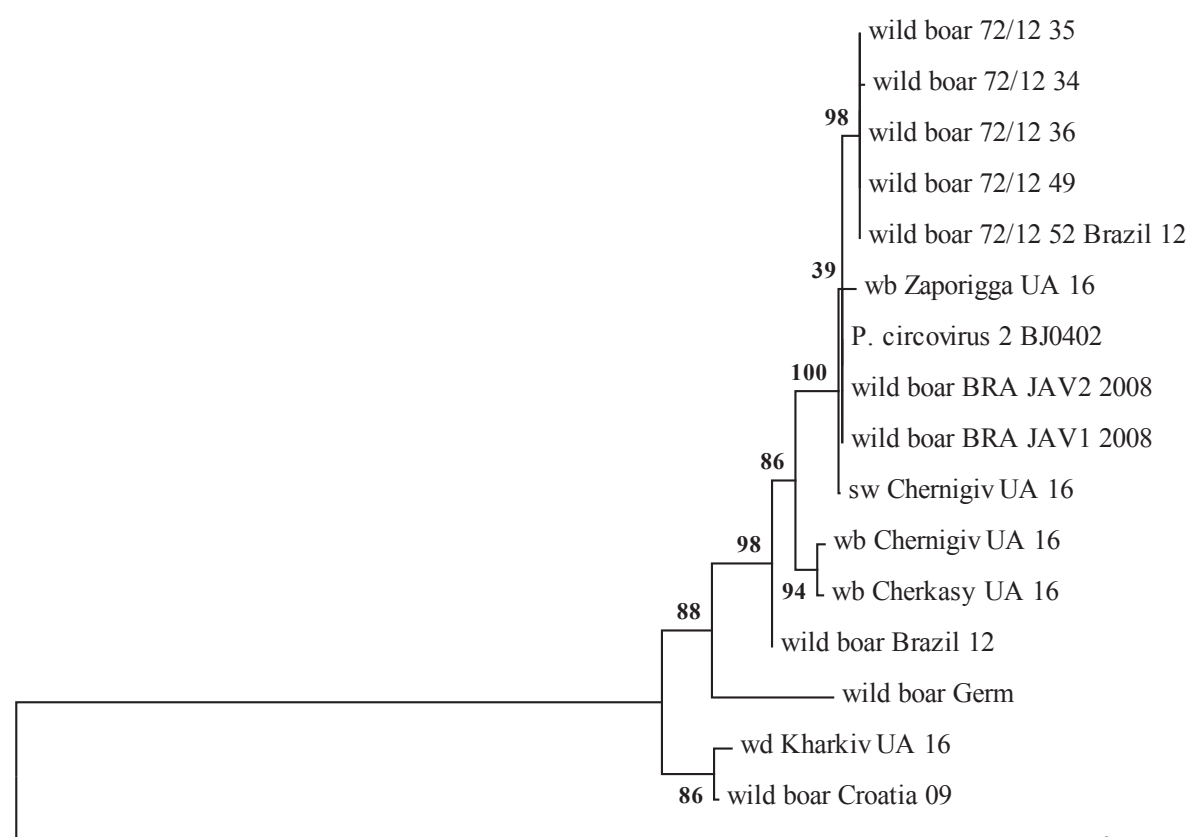

PCV1-Hun Sus scrofa
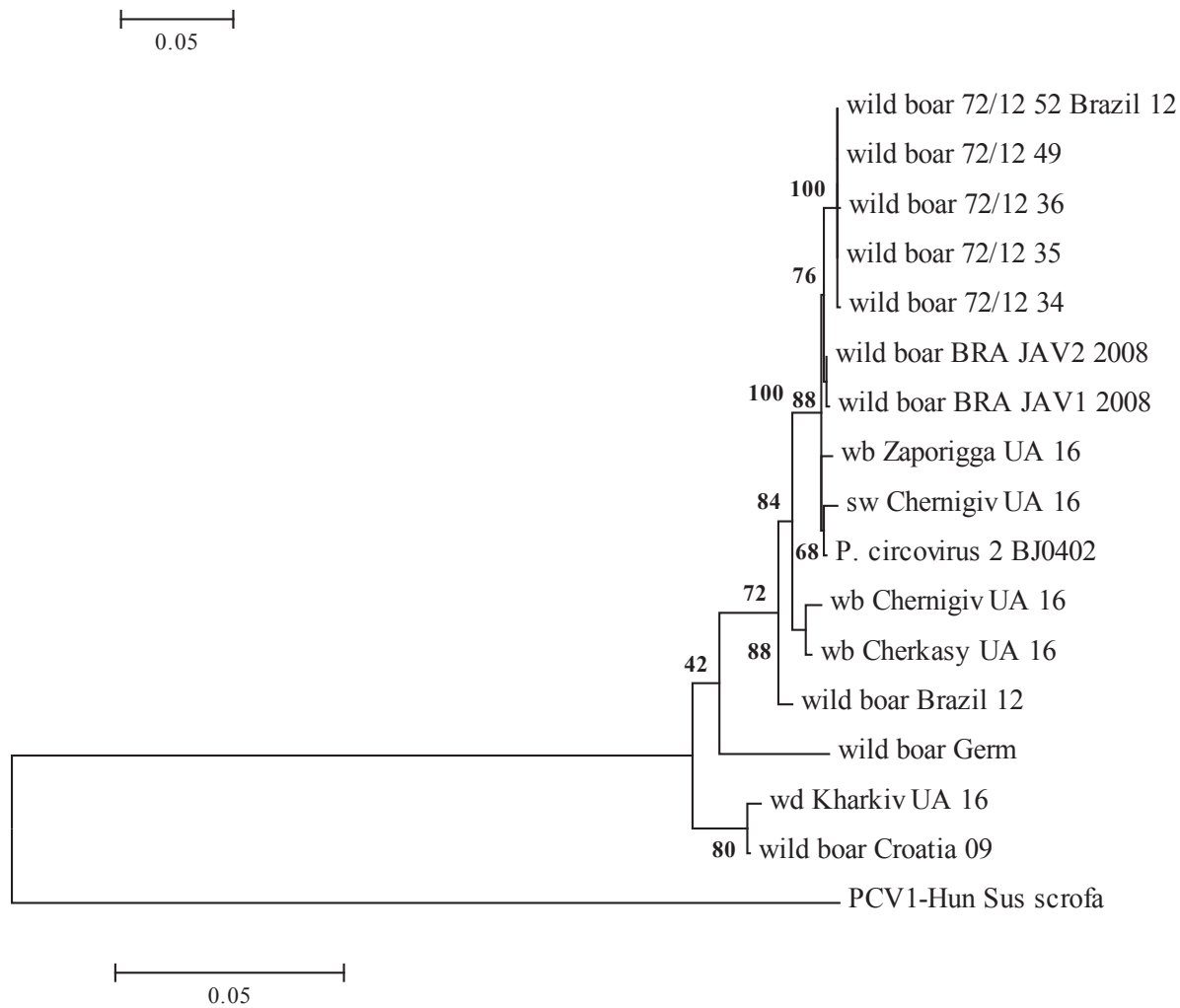

Fig. 1. Molecular Phylogenetic analysis of PCV2 from wild boars (AC) by Maximum Likelihood method.

Fig. 2. Molecular Phylogenetic analysis of PCV2 from wild boars (NK) by Maximum Likelihood method. 


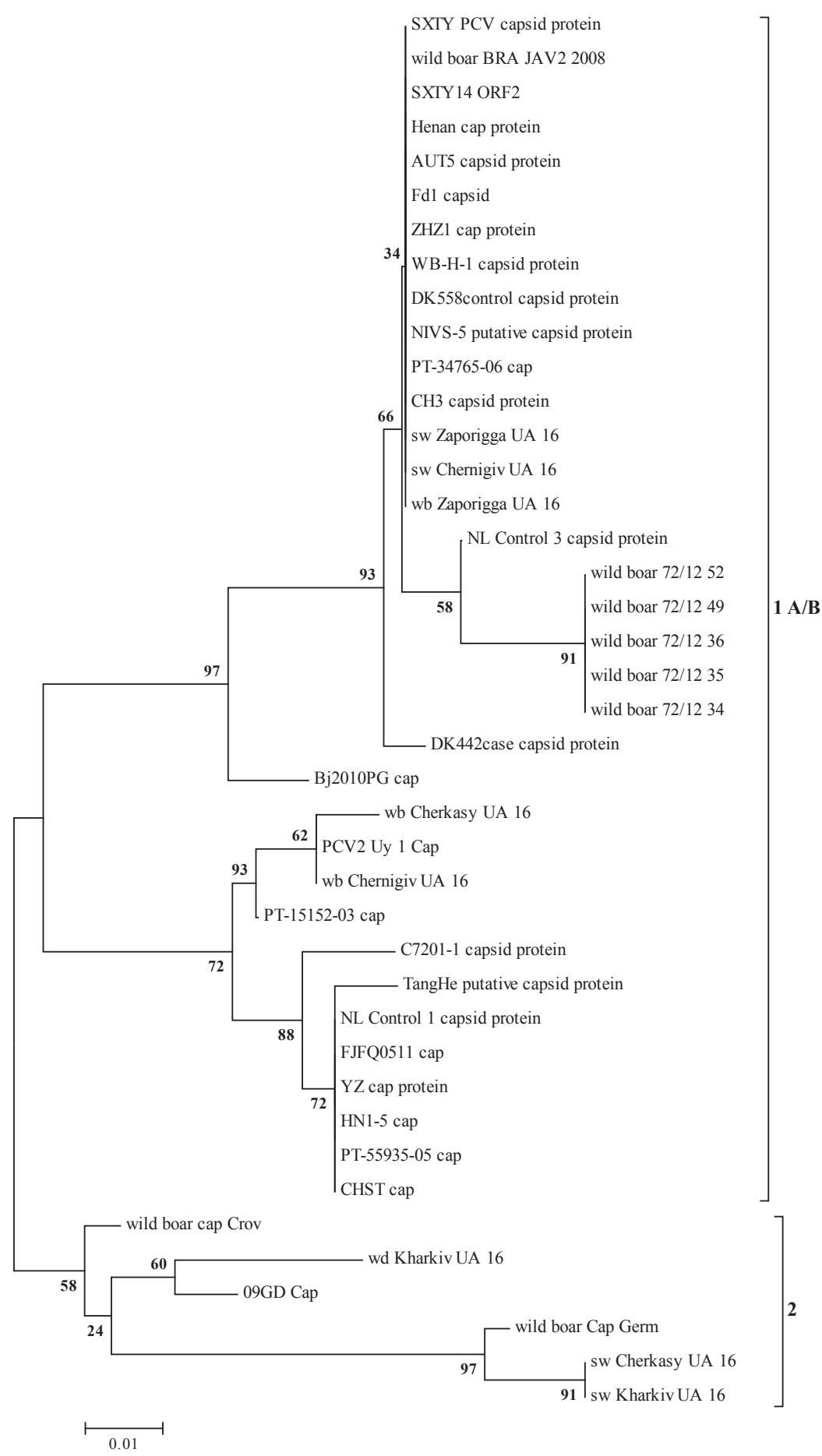

Fig..3. Evolutionary relationships of PCV2 from wild boars and pigs 
on the Kimura 2-parameter model [11]. The tree with the highest log likelihood $(-4739.0701)$ is shown. The percentage of trees in which the associated taxa clustered together is shown next to the branches. Initial tree(s) for the heuristic search were obtained by applying the BioNJ method to a matrix of pairwise distances estimated using the Maximum Composite Likelihood (MCL) approach. A discrete Gamma distribution was used to model evolutionary rate differences among sites $(2$ categories $(+G$, parameter $=$ $0.0500)$ ). The tree is drawn to scale, with branch lengths measured in the number of substitutions per site. The analysis involved 17 nucleotide sequences. Codon positions included were $1 \mathrm{st}+2 \mathrm{nd}+3 \mathrm{rd}$. All positions containing gaps and missing data were eliminated. There were a total of 1743 positions in the final dataset. Evolutionary analyses were conducted in MEGA6 [10].

The tree topology based on the nucleotide and amino acid sequence data coincides which confirms the validity of our conclusions (Fig.1, 2).

Comparison of the circulating strains of wild and domestic animals in Ukraine showed that most of them are quite different and belong to different subgroups. The same situation was described in other European countries. However, the strains isolated from the pigs of the Zaporigga and Chernigiv regions have a common origin with the strain isolated from wild boars in the Zaporigga region. The strains isolated from the pigs from the Cherkasy and Kharkiv regions have a common origin with the strain isolated from wild boars from the Kharkiv region (Fig..3). This fact demonstrates a common origin of described isolates and could be caused by direct transmission of
PCV-2 between wild boars and farm animals, that is not allowed by the biosecurity policy.

The evolutionary history was inferred using the Neighbor-Joining method [12]. The optimal tree with the sum of branch length = 0.28887349 is shown. The percentage of replicate trees in which the associated taxa clustered together in the bootstrap test (1000 replicates) is shown next to the branches [13]. The tree is drawn to scale, with branch lengths in the same units as those of the evolutionary distances used to infer the phylogenetic tree. The evolutionary distances were computed using the p-distance method and are in the units of the number of amino acid differences per site. The analysis involved 41 amino acid sequences. The coding data were translated assuming a Standard genetic code table. All positions containing gaps and missing data were eliminated. There were a total of 124 positions in the final dataset. Evolutionary analyses were conducted in MEGA6 [10].

The phylogenetic tree analyses classified the isolates of this study in two subgroups according to the classification proposed by Grau-Roma et al. (2008) [14]. Based on the subgroup terminology described previously (Olvera et al., 2007) [15], nucleotides 262-267 and amino acids $88-89$ of ORF2 were compared and classified. The nucleotide sequences "CCCCGC", "CCCCTC" and "AAAATC" are the signatures motif for PCV2b subgroup 1A/B, 1C and PCV2a, respectively. The amino acid "PR" was enclosed with subgroup1A/B, while the PL and KI were related with subgroup $1 \mathrm{C}$ and PCV2a (Cheung et al., 2007) [16]. The isolates from Zaporigga, Chernigiv and Cherkasy 1 were divided into $1 \mathrm{~A} / \mathrm{B}$ subgroups together with PCV2 sequences of strains from wild boars 
from Brazil and Germany. The isolates from Charkiv 1 were divided into 2 subgroups together with PCV2 sequences of strain from wild boars from Croatia (Fig. 1-3).

Genetically, the characteristics of Ukrainian isolates of PCV2 showed a high level of diversity. As described, the detected isolates belong to both subgroups ( $1 \mathrm{~A} \backslash \mathrm{B}$ and 2 ) of PCV strains. Additionally to the interesting model that could be applied to other human and animal diseases, this rouses the interest to a continuous monitoring of viral epidemiology, particularly for rapidly evolving viruses like PCV2, and the necessity to share the related information to prevent or promptly act in response to the potential emergence of actual vaccine-immunity escape mutants [17-19].

\section{REFERENCES}

1. Meng XJ. Porcine circovirus type 2 (PCV2): pathogenesis and interaction with the immune system. Annu Rev Anim Biosci. 2013;1:43-64.

2. Segalés J, Allan GM, Domingo M. Porcine circovirus diseases. Anim Health Res Rev. 2005;6(2): 119-42.

3. Opriessnig T, Meng XJ, Halbur PG. Porcine circovirus type 2 associated disease: update on current terminology, clinical manifestations, pathogenesis, diagnosis, and intervention strategies. $J$ Vet Diagn Invest. 2007;19(6):591-615.

4. Cheung $A K$. Porcine circovirus: transcription and DNA replication. Virus Res. 2012;164(1-2):46-53.

5. Timmusk S, Wallgren P, Brunborg IM, Wikström FH, Allan G, Meehan B, McMenamy M, McNeilly F, Fuxler L, Belák K, Põdersoo D, Saar T, Berg M, Fossum $C$. Phylogenetic analysis of porcine circovirus type 2 (PCV2) pre- and post-epizootic postweaning multisystemic wasting syndrome (PMWS). Virus Genes. 2008;36(3):509-20.

6. Guo LJ, Lu YH, Wei YW, Huang LP, Liu CM. Porcine circovirus type 2 (PCV2): genetic variation and newly emerging genotypes in China. Virol J. 2010; 7:273.

7. Kim HK, Luo Y, Moon HJ, Park SJ, Keum HO, Rho $S$, Park BK. Phylogenetic and recombination analysis of genomic sequences of PCV2 isolated in Korea. Virus Genes. 2009;39(3):352-8.

8. Franzo G, Tucciarone CM, Cecchinato M, Drigo M. Porcine circovirus type 2 (PCV2) evolution before and after the vaccination introduction: A large scale epidemiological study. Sci Rep. 2016;6:39458.

9. Jones DT, Taylor WR, Thornton JM. The rapid generation of mutation data matrices from protein sequences. Comput Appl Biosci. 1992;8(3):275-82.

10. Tamura K, Stecher G, Peterson D, Filipski A, Kumar S. MEGA6: Molecular Evolutionary Genetics Analysis version 6.0. Mol Biol Evol. 2013;30(12): 2725-9.

11. Kimura M. A simple method for estimating evolutionary rates of base substitutions through comparative studies of nucleotide sequences. J Mol Evol. 1980;16(2):111-20.

12. Saitou N, Nei M. The neighbor-joining method: a new method for reconstructing phylogenetic trees. Mol Biol Evol. 1987;4(4):406-25.

13. Felsenstein J. Confidence limits on phylogenies: an approach using the bootstrap. Evolution. 1985;39(4): 783-791.

14. Grau-Roma L, Crisci E, Sibila M, López-Soria S, Nofrarias M, Cortey M, Fraile L, Olvera A, Segalés J. A proposal on porcine circovirus type 2 (PCV2) genotype definition and their relation with postweaning multisystemic wasting syndrome (PMWS) occurrence. Vet Microbiol. 2008;128(1-2):23-35.

15. Olvera A, Cortey M, Segalés J. Molecular evolution of porcine circovirus type 2 genomes: phylogeny and clonality. Virology. 2007;357(2):175-85.

16. Cheung AK, Lager KM, Kohutyuk OI, Vincent $A L$, Henry SC, Baker RB, Rowland RR, Dunham AG. Detection of two porcine circovirus type 2 genotypic groups in United States swine herds. Arch Virol. 2007;152(5):1035-44.

17. Li W, Wang X, Ma T, Feng Z, Li Y, Jiang P. Genetic analysis of porcine circovirus type 2 (PCV2) strains isolated between 2001 and 2009: genotype PCV2b predominate in postweaning multisystemic wasting 
syndrome occurrences in eastern China. Virus Genes. 2010;40(2):244-51.

18. Trible $B R$, Rowland $R R$. Genetic variation of porcine circovirus type 2 (PCV2) and its relevance to vaccination, pathogenesis and diagnosis. Virus Res. 2012;164(1-2):68-77.

Генетична характеристика ізолятів цирковірусу свиней 2 типу (ЦВС-2), детектованих від диких кабанів з різних регіонів України

Л. В. Дудар, І. Г. Будзанівська, В. П. Поліщук

Цирковірус свиней 2 типу є надзвичайно розповсюдженим у всьому світі вірусом серед свиней в умовах промислового вирощування. Ураження вірусом призводить до імуносупресивного стану тварин та високої смертності. 3 огляду на велику різноманітність штамів ЦВС-2 у світі, та відмінність між штамами, розповсюдженими в дикій природі та на фермах, необхідною $\epsilon$ характеристика польових ізолятів, виявлених в Україні серед диких кабанів. Мета. Охарактеризувати та диференціювати ізоляти ЦВС-2, виділені від диких кабанів з різних регіонів України. Методи. Філогенентичний аналіз. Результати. Показано, що ізоляти 3 Чернігівської, Запорізької, Черкаської та Харківської областей належать до різних субгруп ЦВС-2 та мають різне походження. Крім того, встановлено досить високий рівень їхньої подібності з ізолятами з Хорватії та Бразилії. Водночас, показано подібність ізолятів, виділених від диких кабанів із Запорізької та Чернігівської областей з такими, що були виділені від свиней 3 промислових господарств. Висновки. Високий рівень генетичного різноманіття був виявлений серед досліджених ізолятів ЦВС-2, виділених від диких кабанів України. Установлений факт подібності деяких ізолятів ЦВС-2 від диких кабанів з ізолятами, від свиней 3 промислових ферм, свідчить про існуючий шлях передачі вірусу між розмежованими популяціями тварин і потребує подальших досліджень.

К л юч о в і с л о в а: цирковірус свиней 2 типу, дикі кабани, філогенетичний аналіз, генетичне різноманіття.

\section{Генетическая характеристика изолятов} цирковируса свиней 2 типа (ЦВС-2), детектированных от диких кабанов с разных регионов Украины

\author{
Л. В. Дудар, И. Г. Будзанивская, В. П. Полищук
}

Цирковирус свиней 2 типа является чрезвычайно распространенным во всем мире вирусом среди свиней в условиях промышленного выращивания. Заражение вируса приводит к иммуносупрессивному состоянию животных и высокой смертности. Учитывая большое разнообразие штаммов ЦВС-2 в мире, и различие между штаммами, распространенными в дикой природе и на фермах, необходима характеристика полевых изолятов, выявленных в Украине среди диких кабанов. Цель. Охарактеризовать и дифференцировать изоляты ЦВС-2, выделенные от диких кабанов из разных регионов Украины. Методы. Филогенентический анализ. Результаты. Показано, что изоляты из Черниговской, Запорожской, Черкасской и Харьковской областей относятся к различным субгрупам ЦВС-2 и имеют разное происхождение. Кроме того, установлено достаточно высокий уровень их сходства с изолятами из Хорватии и Бразилии. В то же время, показано сходство изолятов, выделенных от диких кабанов Запорожской и Черниговской областей, с выделенными от свиней из промышленных хозяйств. Выводы. Высокий уровень генетического разнообразия был выявлен среди исследованных изолятов ЦВС-2, выделенных от диких кабанов Украины. Установленный факт родства некоторых изолятов ЦВС-2 от диких кабанов с изолятами, от свиней из промышленных свиноводческих ферм, указывает на существующий путь передачи вируса между разграниченными популяциями животных и требует дальнейших исследований.

К л юч е в ы е с л ов а: цирковирус свиней 2 типа, дикие кабаны, филогенетический анализ, генетическое разнообразие.

Received 22.11.2017 